УДК 677.11 .08

(C) Д.С. Альбота

Луцький національний технічний університет

\title{
ОБҐРУНТУВАННЯ ПАРАМЕТРІВ ДЕКОРТИКАТОРА ПРЕС- ПІДБИРАЧА ВАЛКІВ СТЕБЛОВО-ВОЛОКНИСТОЇ МАСИ ЛЬОНУ ОЛІЙНОГО
}

У статті вказано на напрямки використання стеблової частини врожаю льону олійного. Запропоновано машину для підбирання валків стеблово-волокнистої маси льону на полі для виготовлення малогабаритних паливних рулонів, або підготовки ї для подальшого вилежування маси з метою отримання волокна.

\section{ЛЬОН ОЛІЙНИЙ, СТЕБЛОВО-ВОЛОКНИСТА МАСА, ДЕКОРТИКАТОР, М'ЯЛЬНІ ВАЛЬЦ, ВОЛОКНО, ПАЛИВНІ РУЛОНИ}

Постановка проблеми. Інтерес до вирощування льону олійного обумовлено такими факторами:

- попитом на лляну олію, яка застосовується при виробництві лакофарбового покриття, лінолеуму, харчових продуктів, лікарських препаратів і т. д.

- високою рентабельністю вирощування льону. Один гектар посіву льону олійного забезпечує такі самі економічні показники, як один гектар вирощування озимої пшениці з урожаєм не менше 40 ц/га.

Разом 3 цим солома льону $є$ цінною сировиною для отримання продукції різного функціонального призначення, в тому числі прядильного волокна. Якість збирання льону визначається збереженням всього врожаю за умови мінімізації витрат на цю технологічну операцію. 3 соломи льону одержують якісні ізоляційні панелі, вони легкі, мають низьку теплопровідність.

Перспективною $\epsilon$ також технологія виготовлення композиційних матеріалів 3 використанням луб'яних волокон. Використання лубу зумовлене його перевагами: висока міцність на розрив та пружність на згин порівняно з лляним волокном

Проблемою, яку необхідно вирішити під час збирання льону олійного зернозбиральним комбайном $\epsilon$ використання стеблової частини врожаю, адже стебла льону містять волокно. При врожайності 15-20ц/га насіння на полі у валках залишається до 40 ц/га стеблово-волокнистої маси. Ї̈ї важко загорнути в грунт, крім 
того, вона повільно розкладається. Щоб уникнути таких труднощів, перед оранкою потрібно використовувати важкі дискові борони, а за потреби - повторити дискування у взаємно перпендикулярних напрямках i навіть така підготовка не гарантує позитивного результату.

Аналіз останніх досліджень та публікацій. В Україні стебла соломи льону олійного не переробляються, а лише спалюються на полях господарств, оскільки вважається, що в них знаходиться мала кількість волокон i виділення його $\epsilon$ нерентабельним. Але, світовий досвід провідних вчених: В.В. Живетіна, Л.Н. Гінзбурга, Є.Л. Пашина, Н.М. Федосової (Росія), Р. Козловського (Польща), П.Л. Каполетто (Італія), Чурсіної Л.А., Тіхосової Г.А., Дідуха В. Ф., Ягелюк С. В. (Україна), які присвятили даному питанню багато робіт, свідчить, що солома льону олійного є цінною сировиною для одержання інноваційної продукції [1-4].

Аналіз світового досвіду використання продукції з льону олійного свідчить, що важливим i актуальним завданням на сьогоднішній день $є$ використання всього закладеного в рослині потенціалу із найменшими втратами волокна, насіння та відходів у вигляді полови та костриці. У той же час збирання льону олійного за традиційною технологією зернозбиральними комбайнами призводить до втрат волокнистої частини урожаю у стерні, яка залишається на полі висотою $10-20 \mathrm{~cm}$, а зібрана солома пошкоджується та засмічується половою із залишками розгалуженої частини стебел, які важко відділити під час первинної переробки на волокно.

Мета дослідження - запропонувати технологію виробництва малогабаритних рулонів шляхом декортикації стеблово-волокнистої маси льону.

Результати дослідження. Для вирішення проблеми звільнення полів від залишеної стеблово-волокнистої маси запропоновано шляхи подальшої переробки сировини в залежності від стадії стиглості льону олійного.

Якщо в обмолоченій масі матеріалу є більш-менш якісне волокно, то його доцільно після плющення м'яльними вальцями формувати у зручні для транспортування рулони для подальшої переробки.

Таке волокно знаходить широке використання в текстильній промисловості у суміші 3 іншими натуральними i хімічними волокнами для виробництва текстильних виробів. Це викликає зміни в технологіях збирання та одержання волокна, які 
спрямовані перш за все на ресурсозбереження. Так на збиранні льону застосовують адаптовані, високопродуктивні сільськогосподарські машини загального призначення: косарки, зернозбиральні комбайни, перевертачі валків, рулонні преси і інша техніка. Використання цієї техніки дозволяє значно скоротити матеріальні та енергетичні витрати. Слід зазначити ще одну позитивну особливість цієї технології. Якщо при збиранні використовують косарки, то вони забезпечують зрізання стебел на висоті 5-7см від поверхні грунту. Таким чином у залишках відсутне волокно або низької якості, що загалом підвищує загальну якість одержаного волокна з трести.

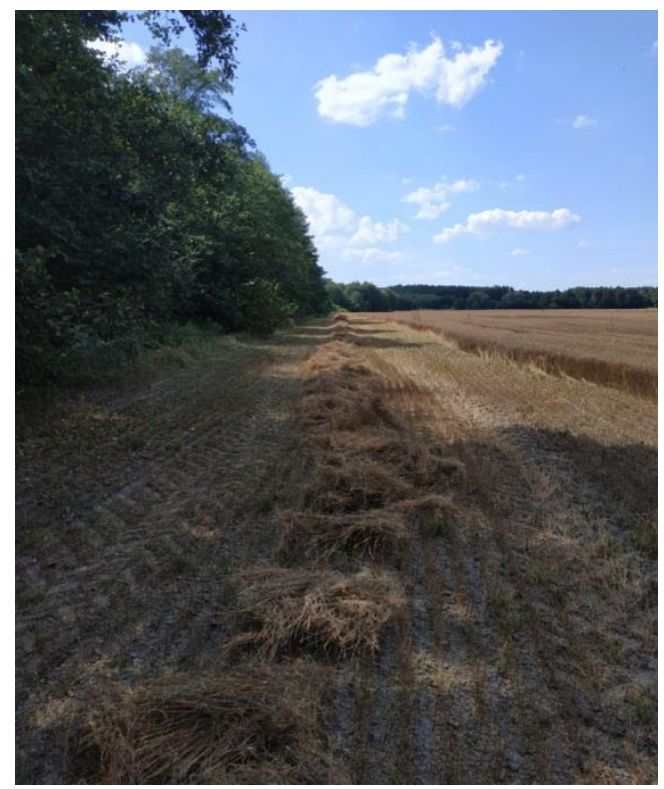

Рис. 1 - Стеблово-волокниста маса льону олійного після обмолочування

Якщо в силу певних обставин не вдається зібрати стеблово-волокнисту масу і відправити ії на виготовлення волокна, можливий інший напрям іiі використання. Це отримання високоефективних паливних матеріалів. Окрім цього паливні матеріали можна виготовляти і з відходів переробки стеблової частини врожаю льону олійного. 
При цьому на зернозбиральному комбайні необхідно передбачити подрібнювальний пристрій для отримання дрібної фракції з подальшим накопиченням у відповідний причіп. Потім із подрібненої сировини можна виготовляти паливні брикети чи пелети.

Інший варіант обробки передбачає використання декортикатора із кількома парами вальців різної конструкції, який зменшує пружні властивості стебло-волокнистої маси льону, що дозволяс на виході із декортикатора формувати малогабаритні паливні рулони.

Таким чином вирішується проблема з утилізації стеблової частини врожаю та створюються нові види продукції. Льон має значний енергетичний запас, так як паливо на його основі має хорошу тепловіддачу.

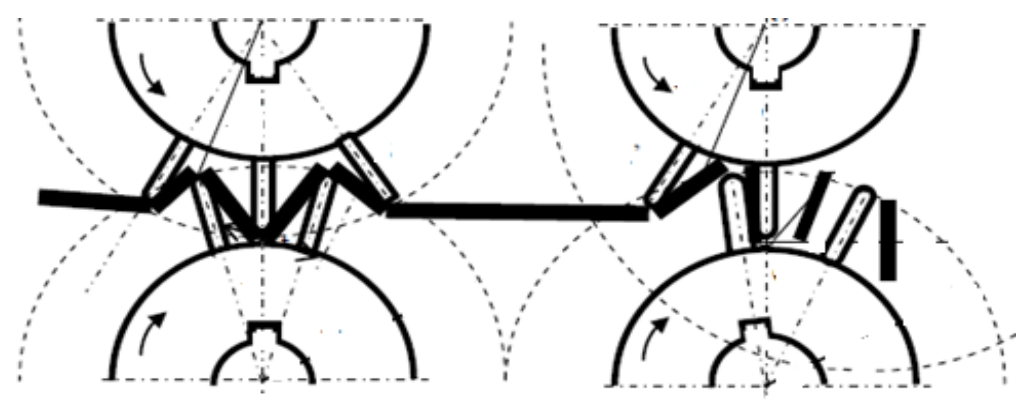

Рис. 2 - Схема взаємодії рифлів м'яльних вальців з стеблом луб'яних культур

Декортикація стебел включає операція зламу, яка характерна для процесу м'яття. Порушення зв'язку волокна 3 деревиною у м'яльних вальцях відбувається за рахунок згину-злому стебел. Щоб забезпечити максимальне руйнування деревини $\mathrm{i}$ мінімальне пошкодження волокна м'яльними вальцями, важливо знати фізичну суть процесу руйнування конструкції стебла при згині. [4]

Процес згину для соломи і трести проходить по-різному. При згині соломи спочатку спостерігається зминання у верхній частині стебла. Потім стебло сплющується і розтріскується його деревина . На кінцевому етапі злому деревина руйнується, а луб'яні волокна у нижній частині натягуються, частково зміщуються відносно деревини, але не відшаровуються. Під час злому трести спостерігається повне розтріскування деревини і відшарування 
волокна від деревини. Це свідчить про те, що у трести зв'язок між волокнистим шаром i деревиною слабший, тому треста краще піддається механічній переробці для отримання волокна.

Аналіз вузла очищення сирцю 3 лляної трести м'яльнотіпального агрегату, який складається 3 пари м'яльних гладких вальців, пари рифлених м'яльних вальців які характеризуються малим радіусом закруглення кромки рифлів і відносно великою іiі висотою порівняно 3 кроком та розміщених між ними пари плющильних вальців показує, що після його модернізації можна використати для зменшення пружних властивостей стеблововолокнистої маси льону олійного. [3]

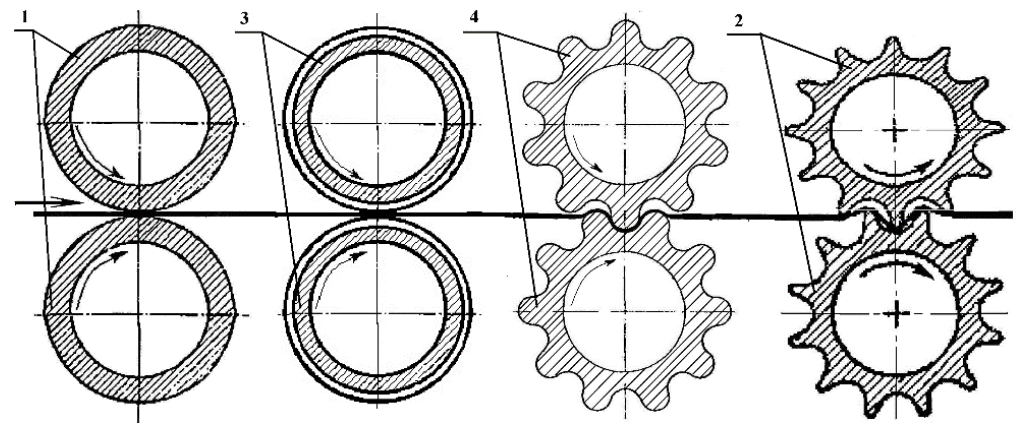

Рис. 3 - Вузол очищення сирцю з лляної трести м'яльно-тіпального агрегату: 1 - м'яльні гладкі вальці; 2 - рифлені м'яльні вальці крутого рифлення; 3 - плющильні вальці; 4 рифлені м'яльні вальці пологого рифлення.

Для реалізації усього вище сказаного пропонується машина, для підбирання стеблово-волокнистої маси льону олійного 3 валків зі землі, яка передбачає операцію декортикації. Машина причіпна та дозволяє зменшити пружні властивості матеріалу при його підготовці до вилежування на полі або формуванні малогабаритних рулонів.

Принцип роботи машини: за допомогою транспортерного підбирача відбувається підбирання валка стеблово-волокнистої маси та переміщення до декортикатора, у якому відбувається зменшення пружних властивостей стебел. Після проходження сировини через декортикатор оброблена солома попадає у камеру пресування, в якій відбувається процес формування рулонів. Готовий рулон потрапляє на вивантажувальний транспортер, який переміщує рулон на транспортний засіб. 


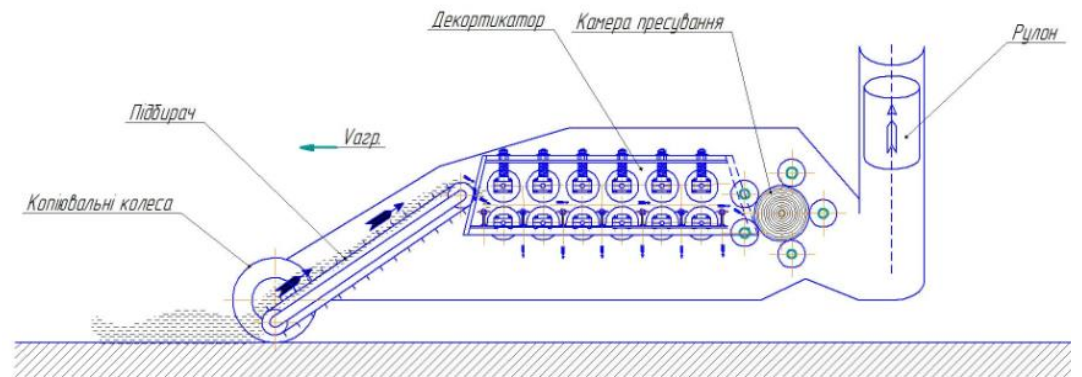

Рис. 4 - Функціональна схема машини з декортикатором для формування малогабаритних рулонів

Дану машину можна використовувати також для зменшення об'єму валка стеблово-волокнистої маси, що є аналогією функції обертача стрічки льону-довгунця. Процес декортикації необхідно застосовувати коли валок льону надто об’ємний, його потрібно пром'яти і залишити на полі для ефективнішої подальшої заготівлі сировини на волокно.

Висновки. Окреслена проблема збирання льону олійного та вказані перспективи використання стеблової частини вражаю на коротке неорієнтоване волокно або паливні матеріали. Проведено аналіз процесу декортикації лубоволокнистих матеріалів і запропоновано функціональну схему машини, яка включає декортикатор для підбирання стеблово-волокнистої маси льону олійного.

\section{Література}

1. Живетин В.В. Масличный лен и его комплексное развитие / В.В. Живетин, Л.Н. Гинзбург. - М.: ЦНИИЛ- КА, 2000. - 389 с.

2. Тіхосова Г.А. Наукові основи комплексної переробки стебел та насіння льону олійного: [монографія] / Л.А. Чурсіна, Г.А Тіхосова., О.О. Горач, Т.І. Янюк. - Херсон: Олді-плюс, 2011. $356 \mathrm{c}$.

3. Дідух В.Ф., Буснюк В.В., Бойчук Б.В. Ягелюк С.В. Машина для формування паливних рулонів Патент на КМ № 135725 A01D43/04, A01D45/06 (2006.01) A01F15/07. Опуб. 10.07.2019, бюл.№13. 


\section{Сільськогосподарські машини. Випуск 43}

4. Studying the possibilities of producing fuel materials from oily flax wastes in the conditions of Western Pollissya. / S. Yaghelyuk, V. Diduh, V. Tkachyuk - Ştiinţa agricolă / Universitatea agrară de stat din Moldova, - Chişinău, 2018 - nr. 2 (2018) - 158-163

5. Ягелюк С.В., Дідух В.Ф., Кірчук Р.В. Дослідження процесів збирання льону олійного 3 використанням стеблової частини врожаю/ товарознавчий вісник. - 2019 . - Випуск 12

6. Березовський Ю.В. Використання нових технічних рішень у промисловому виробництві лляної продукції /Наука та інновації.2016. - Т.12 №4

7. Клевцов К.М. Визначення оптимальних технологічних параметрів декортикації луб'яної сировини / К.М. Клевцов // Вісник Хмельницького національного університету. - 2015. - № 5 (227). C. $97-101$.

8. Первичная обработка льна и других лубяных культур / В.В. Марков. - М.: Легкая и пищевая пром- сть, 1981. - С. 162-169. 